\title{
Impact of Organizational Justice on Affective Commitment: Mediating role of Psychological Ownership and Organizational Identification
}

\author{
HooreenTasneem Ahmed \\ Foundation University Islamabad
}

\begin{abstract}
This research was proposed to test the research model was to observe the association of distributive and procedural justice perceptions on affective commitment with a mediating role of psychological ownership and organizational identification. Based on the data gathered from 250 respondents were used for the analysis. Analysis was done using Simple and Multiple Regression and Baron and Kenny tests and the results supported thatprocedural justice perceptions has a remarkable influence on affective commitment. Psychological Ownership and Organizational Identification, both, were also found to fully mediate the linkbetween procedural justice perceptions and affective commitment.
\end{abstract}

\section{Introduction:}

The concept of organizational justice has been extensively studied in the Western countries for several decades. The western culture is moving towards equality in the workplace. They are striving to provide employees with an environment where they can develop fair perceptions about their organization. However, in Pakistan this area is untapped and needs attention from the researchers. Much of the scholarly attention has been given to the field of organizational justice perceptions and it has become one of the recurrently researched topics (Cropanzano \& Greenberg, 1997). It is deemed by many scholars that in order to develop favorable attitude towards the organization, employers must strive to establish organizational justice perceptions. If employees are treated impartially and fairly compensated, then it will motivate and encourage them to invest their time, energy, experience and education in the organization (Janssen, Lam, and Huang, 2009). Organizational Identification is also one of the most vital elements for the development of organizational justice perceptions. Individuals who perceive the outcomes and procedures of a firm as fair and unbiased are likely to identify themselves with their organization (Tyler and Blader, 2000, 2003).

Another facet of today's organization is development of psychological ownership among employees. When employees are the target of ownership it brings positivity in their perceptions as well as attitudes. This ownership can be formal or informal (Peirce, Kostona \& Dirkes, 2001). Feelings of "possessiveness" develop when individuals have fair justice perceptions in their minds. Thus, there exists a positive relationship between organizational justice perceptions and psychological ownership (Chi \& Han, 2008). As far as a positive link between psychological ownership and affective commitment is concerned, many scholars have validated this (O' Driscoll, Pierce \& Coughlan, 2006) whereas the mediating effect of psychological ownership in various contexts can also be witnessed.

\subsection{Knowledge Gap:}

This research is an effort to enhance the link between organizational justice and affective commitment by realizing psychological ownership and organizational identification as mediating variables (Siegeret al., 2011). The current research compares the specific role and weight of psychological ownership with organizational identification as a mediator and aims to find out whether the mediators show full or partial mediation effect.

\subsection{Problem statement:}

Considering the aforementioned discussion, the study aims to explore the link of organizational justice on affective commitment taking psychological ownership and organizational identification as mediators.

\subsection{Objectives:}

The main objectives of the research are:

1. To understand the effect of organizational justice on affective commitment with psychological ownership and organizational identification as mediators in the banking industry.

2. To determine the association of distributive justice and affective commitment by taking psychological ownership and organizational identification as mediators.

3. To understand the effect of procedural justice on affective commitment by taking psychological ownership and organizational identification as mediators. 


\subsection{Significance of the Study:}

The present study constitutes valuable contribution to existing body of knowledge by exploring the mediating effects of organizational identification along with psychological ownership. This research domain is one of a new kind as it tends to inspect the organizational justice and affective commitment with psychological ownership and organizational identification as mediators in the banking industry of Pakistan. This study is an enhancement of the model by Sieger et al., 2011, containing organizational identification as a mediator. Research suggests that those employees avail opportunities to make contributions who strongly identify themselves with their organization (Cho \& Treadway, 2010).

\section{Literature Review:}

The topic of justice has been of wide interest in philosophical studies. It extends back to Plato and Socrates time (Colquitt et al., 2001). Justice means "oughtness" or "righteousness". Employees work correctly if justice is present, but if it's not then they tend to use illicit methods to get their rights (Choudhry, Philip, \& Kumar, 2011).

According to literature organizational justice isdivide into two main types of justice namely 1) Distributive Justice and 2) Procedural Justice (Fu \&Lihua, 2012). Distributive justice was evolved by a theory presented by Adam Smith (1965). According to this theory, employees put their effort and education in doing their job and as a result receive different outcomes or rewards in the form of pay, promotion etc. They compare relevant inputs (i.e. contributions in the form of experience, education) with output of others. This comparison determines equity or inequity. The concept of distributive justice has developed from this theory. Distributive Justice is "when employees perceive fairness of the outcomes that they receive in return for their inputs". Perception of injustice of outcomes will yield dissatisfaction in an employee in the form of lower work performance (Greenberg, 1993).

Employees not only perceive fairness in the distribution of outcomes but also the procedures that assess their results/outcomes. This is known as Procedural Justice that has a focus on perceiving fairness of means ( Usmani\& Jamal, 2013).

Psychological ownership is defined as "a state in which individuals feel as though the target of ownership or a piece of target is theirs" (Peirce, Kostona \& Dirkes, 2001). The term psychological ownership represents the feeling of possessiveness and of being psychologically tied to an object (Peirce et al., 2003). Psychological Ownership generally consists of self-efficacy, accountability, belongingness and identity (Avey et al., 2008).

Ever since 1960's, in organizational studies the popular term known is organizational identification. O'Reily and Chatman (1986) have defined identification as the process of "an individual accepting influence from a group or organization in order to establish and maintain a relationship.

Porter et al. (1974) defined commitment as "the strength of an individual's identification with and involvement in a particular organization". "Organizational commitment is an employee's belief in the organization's goals and values and an aspiration to remain a member of the organization as well as faithfulness to the organization" ( Mowday et al., 1982; Hackett et al., 2001).

According to literature, organizational commitment consists of two views 1) behavioral view 2) attitudinal view (Mowday et al., 1982). Behavioral view of commitment is the process by which individuals develop attachment to their actions not the organization, whereas the attitudinal aspect views commitment as an attitude showing nature of the association between the employee and the organization. According to Meyer and Allen (1991), there are three main types of commitment namely 1) Affective 2) Continuance and 3) Normative.

Affective Commitment refers to an employee's emotional attachment to, identification and involvement in the organization (Allen and Meyer, 1990). Affective Commitment means that an employee wishes to stay a part of the organization. Continuance Commitment is "employee's perceived cost of leaving the organization" and Normative Commitment denotes "a feeling of obligation to stay with the organization" (Meyer et al., 2002).

Equity theory postulates that personnels receiving resource allocations as a result of their contribution to the organization then they will perceive justice (Adams, 1965). Under Accountability considerations, individuals try to identify the person responsible for making decisions which shape their attitudes towards that person. Pay, promotion and compensation are set by the organization (Walumbwa et al., 2009). If employees perceive the outcome as just, then they will identify the organization as just. This will create favorable judgments among employees which would also cultivate state of possessiveness i.e. ownership for the organization psychologically (Beggan, 1992). According to Janssen, Lam, and Huang (2009), when resource investments of employees are fairly compensated this will lead to highly motivated to dedicate their personal resources i.e. education, experience, skill and time. Thus high levels of distributive justice will upsurge employees willingness to put in their personal resources. Employees' personal resource investments will eventually bring about psychological ownership (Pierce et al., 2001, 2003).

Similarly employees who are provided with profit sharing plans especially ESOP (employee stock ownership plan) are likely to demonstrate positive attitudes and behavior. Involving employees in profit sharing 
plans, it is likely that their rewards will bring about organizational profits (Welbourne et al., 1995). These plans help the employees to balance their input and output ratios with that of the organization and leads to augmented levels of distributive justice. Thisaugmented organizational justice will create feelings of psychological ownership among employees (Pierce \& Rodgers, 2004).

Procedural justice can be crafted if employees are involved in decision making in two ways (Lind, Kanfer, \&Earley, 1990; Roberson, Moye, \& Locke, 1999). These two reasons: 1) It provides them a chance to be a part of and have their say in the decision making process (process control). 2) Employees can directly influence the decision making process and outcomes (decision control) (Brett \& Goldberg, 1983; Thibaut \& Walker, 1975). This in turn provides employees with greater autonomy in procedures which eventually escalates the perception of procedural justice (Folger\&Cropanzano, 1998; Korsgaard et al., 1995; Pierce et al., 2004). Autonomy in decision making process fosters psychological ownership among employees (Pierce et al., 2001). Previous studies also suggest that sharing business information like strategies and performance and conveying feedback about organizational decisions in time will enhance employees' perception of procedural justice (Korsgaard et al., 1995; Sapienza \& Korsgaard, 1996).

Previous researches have highlighted the imperative role that organizational justice can play in developing organizational identification among individuals (Olkkonen \& Lipponen, 2006). According to Tyler and Blader, 2000, 2003 justice perceptions help employees in forming identification with their organization. When employees have a fair justice perception in their mind, it would result in credibility and respect for the organization which will encourage employees to identify themselves as part of that particular organization (Lind \& Tyler, 1988).

Both fairness of outcomes (i.e. distributive justice) and fair procedures (i.e. procedural justice) is an important predictor of organizational identification (Tyler et al., 1996; Tyler \& Blader, 2003).

Many previous researches have been conducted on psychological ownership as a mediating variable. In a research conducted by Shu\& Peck, (2011), Psychological ownership along with affective reaction has been studied as a mediator including other variables like actual ownership, changes in affect and loss aversion. Full mediation effects were found among the variables.

Avey, Wernsing \& Palanski, (2012) also studied the psychological ownership as a mediator. Mediation of psychological ownership was tested with ethical leadership, well-being of personnel and job satisfaction. Psychological ownershiphas been observed to have significant relationship between ethical leadership and satisfaction with job.

Another study carried out by Mayhew et al., (2007) observed the mediation effect of Psychological Ownership (both job based and organizational based). Other constructs in the study were satisfaction with the job, organizational commitment, job design, and autonomy and work attitudes. Partial mediation of job based psychological ownership and substantial mediation of organization based psychological ownership has been revealed by the outcomes of several researches.

Organizational identification as a mediating variable has been exploredby many scholars. In one of the study carried out by Chughtai\& Buckley (2009), organizational identification has been tested as a mediator along with trust and school outcomes. The results showed full mediation of organizational identification. Similarly Walumbwa, Cropanzano\&Hartnell (2009) studied organizational identification as a mediator with organizational justice, leader-member exchange, voluntary learning attitude and performance.

According to previous researches, an affirmative link exists between Organizational justice and Organizational commitment (Cohen-Charash and Spector, 2001; Folger and Konovsky, 1989; Linda and Ping, 1996). Procedural Justice showed a much more positive significant relationship with organizational identification with organizational commitment as compared to distributive justice (Folger and Konovsky, 1989). Procedural justice is a better predictor of organizational commitment than distributive justice. (Sweeney and McFarlin, 1993).Similarly, Loi et al., (2006) found that affective commitment has a strong affirmative linkage with procedural justice other than continuance and normative commitment. If fair procedures are carried out in the organization, it would lead to a strong emotional attachment among employees.

Therefore, the proposed research model can be tested taking affective commitment as a dependent variable. Following hypothesis can be generated in context with the theoretical framework:

H1: A positive association exists between Distributive Justice Perceptions and Affective Commitment. H2: A positive association exists between Procedural Justice Perceptions and Affective Commitment. H3: Psychological Ownership mediates the effect of Distributive Justice Perceptions on Affective Commitment. H4: Psychological Ownership mediates the effect of Procedural Justice Perceptions on Affective Commitment. H5: Organizational Identification mediates the effect of Distributive Justice Perceptions on Affective Commitment.

H6: Organizational Identification mediates the effect of Procedural Justice Perceptions on Affective Commitment. 


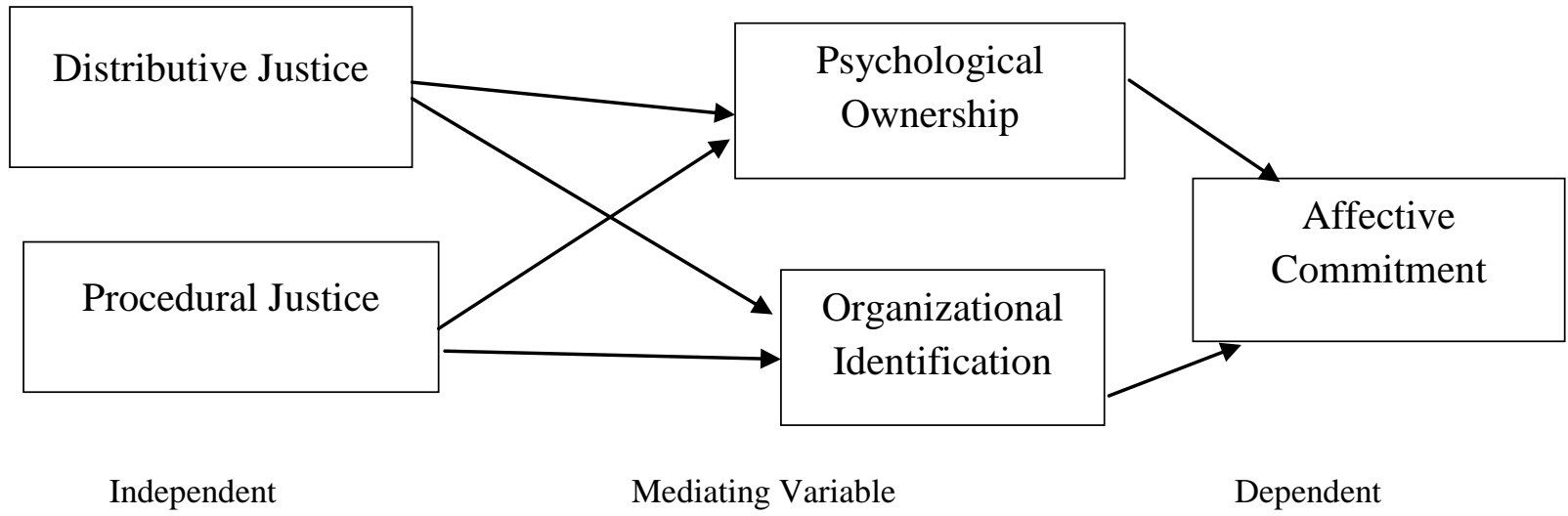

\section{Research Methodology}

The study was cross-sectional and causal in nature. Respondents of the study were 250 employees chosen from banks in twin cities of Pakistan i.e. Rawalpindi and Islamabad. Employees were selected from Standard Chartered, Askari Bank Limited, United Bank Limited, Meezan Bank Limited and Faysal Bank Limited. Data was collected through questionnaire. Questionnaire of distributive and procedural justice by Colquitt (2001) containing 11 items was adopted. A seven item scale developed byVanDyne and Pierce (2004) was used to assessPsychological ownership. Six items of Organizational identification were taken fromMael and Ashforth (1992) whereas an eight item scaledeveloped by Allen and Meyer (1990) was used to represent Affective Commitment.The reliability of all constructs was measured using Cronbach's Alpha for internal consistencywhich came out to be 0.70 .

\section{Data Analysis and Discussion}

We used Simple and Multiple Regression and Baron and Kenny Test for assessing the data.

\subsection{Hypothesis Testing}

Table 4.1 Multiple Regression Analysis

\begin{tabular}{|l|l|l|l|}
\hline & \multicolumn{1}{|c|}{ Affective Commitment } & \multicolumn{1}{c|}{ p value } \\
\hline Independent Variables & \multicolumn{1}{|c|}{ Beta } & \multicolumn{1}{c|}{ t value } & \\
\hline Distributive Justice & -.113 & -1.296 & .000 \\
\hline Procedural Justice & & & \multicolumn{2}{|c|}{} \\
\hline
\end{tabular}

Table 4.2 Simple Regression Analysis

\begin{tabular}{|l|c|c|c|}
\hline & \multicolumn{3}{|c|}{ Affective Commitment } \\
\hline & Beta & t value & p value \\
\hline $\begin{array}{l}\text { Psychological } \\
\text { Ownership }\end{array}$ & .286 & 3.369 & .001 \\
\hline $\begin{array}{l}\text { Organizational } \\
\text { Identification }\end{array}$ & .398 & 4.690 & .000 \\
\hline
\end{tabular}

Table 4.3 Baron and Kenny for mediation analysis with psychological ownership

\begin{tabular}{|l|c|c|}
\hline & t value & p value \\
\hline $\begin{array}{l}\text { Procedural justice and affective } \\
\text { commitment }\end{array}$ & 3.957 & .000 \\
\hline
\end{tabular}

Table 4.4 Baron and Kenny for mediation analysis with organizational identification

\begin{tabular}{|l|c|c|}
\hline & t value & p value \\
\hline $\begin{array}{l}\text { Procedural justice and } \\
\text { affective commitment }\end{array}$ & 5.418 & .000 \\
\hline
\end{tabular}

The first hypothesis of our study statedthat a positive association exists between Distributive Justice Perceptions and Affective Commitmentis observed to be false as per regression analysis. Our second hypothesis, a positive association exists between Procedural Justice Perceptions and Affective Commitment, was found to be true through the regression analysis which showed that procedural justice perceptions are affirmatively related to 
affective commitment with the strength of $37.1 \%$ as shown in table 4.1 . The outcomes were consistent with the findings of Sweeney and McFarlin (1993), Cohen-Charash\& Spector (2001) and Colquitt et al., (2001).

As conditions of mediation explained/devised by Baron and Kenny test could not established for hypothesis 3 of the study which stated thatPsychological Ownership mediates the effect of Distributive Justice Perceptions on Affective Commitment and hypothesis 5 of the study which stated that organizational identification mediates the relationship on distributive justice perceptions and affective commitment were rejected.

Hypothesis 4 of the study stated that Psychological Ownership mediates the effect of Procedural Justice Perceptions on Affective Commitment. It was found that psychological ownership mediates the relationship of procedural justice perceptions as $\mathrm{p}$ value was observed to be less than 0.05 as shown in table 4.3. Hence Hypothesis 4 is validated. Sixth hypothesis of the study stated that organizational identification mediates the effect of procedural justice perceptions on affective commitment found to be true. The results are consistent with the outcomes of Kets de Vries (1993) and Pierce et al., (2001).

\subsection{Conclusion}

The key purpose of this study was to explore the linkage of organizational justice perceptions on affective commitment of bank employees. Our study validated that:

- Distributive Justice Perceptions have been found to have no relationship with affective commitment. As conditions for mediation were not fulfilled therefore, mediation could not be tested on this relationship.

- Procedural justice perceptions have been found to have a positive relationship with affective commitment. It was also observed that psychological ownership fully mediates the relationship of distributive justice perceptions and affective commitment.

- It was observed that Organizational identification fully mediates the relationship between procedural justice perceptions and affective commitment.

\section{References:}

[1]. Adams, J. S. (1965). Inequity in social exchange.In Berkowitz, L (Ed.), Advances inexperimental social psychology (Vol. 2, pp. 267-299). New York: Academic Press.

[2]. Allen, N. J., \& Meyer, J. P. (1990). The measurement and antecedents of affective, continuance and normative commitment to the organization.Journal of Occupational Psychology, 63(1), 118.

[3]. Avey, J. B., Avolio, B. J., Crossley, C. R., \&Luthans, F. (2008). Psychological ownership: Theoretical extensions and analysis of a multi-dimensional theory-based measure. Journal of Organizational Behavior, 29, 1-19.

[4]. Avey, J. B., Wernsing, T. S., \&Palanski, L.E. (2012).Exploring the Process of Ethical Leadership: The Mediating Role of Employee Voice and Psychological Ownership.Journal of Business Ethics. 107, 21-34.

[5]. Beggan, J. K., (1992). On the social nature of nonsocial perceptions: The mere ownership effect. Journal of Personality and Social Psychology, 62(2), 229-237.

[6]. Brett, J. M., \& Goldberg, S. B. (1983). Mediator-advisors: A new third-party role. In M. Bazeman\& R. Lewicki (Eds.), Negotiating in organizations (pp. 165-176). Beverly Hills, CA: Sage.

[7]. Cropanzano, R., \& Greenberg, J. (1997). Progress in organizational justice: Tunneling through the maze. In C. L. Cooper \& I. T. Robertson (Eds.), International review of industrial and organizational psychology (Vol. 2, pp. 317-372). New York: Wiley.

[8]. Choudhry, N., Philip, P. J., \& Kumar, R. (2011).Impact of Organizational Justice on Organizational Effectiveness.Industrial Engineering Letters, 1 (3), 18-24.

[9]. Cheney, G. (1983). On The Various and Changing Meanings of Organizational Membership: A Field Study of Organizational Identification, CommunicationMonographs, 50(4), pp. 342- 362.

[10]. Chi, N., \& Han, T. (2008).Exploring the linkages between formal ownership and psychological ownership for the organization: The mediating role of organizational justice.Journal of Occupational and Organizational Psychology, 81(4), 691-711.

[11]. Cho, J., \&Treadway, D.C. (2010). Organizational identification and perceived organizational support as mediators of the procedural justice-citizenship behavior relationship: A cross-cultural constructive replication. European Journal of Work and Organizational Psychology,20 (5), 631-653.

[12]. Chughtai, A. A., \& Buckley, F. (2009). Linking trust in the principal to school outcomes: The mediating role of organizational identification and work engagement. International Journal of Educational Management, 23(7), 574-589.

[13]. Cohen-Charash, Y., \& Spector, P.E. (2001). The role of justice in organizations: a meta-analysis. Organizational Behavior and Human Decision Process, 86, pp. 278-321.

[14]. Colquitt, J. A., Conlon, D. E., Wesson, M. J., Porter, C. O. L. H., \& Ng, K. Y. (2001). Justice at the millenium: A meta-analytic review of 25 years of organizational justice research. Journal of Applied Psychology, 86(3), 425-445.

[15]. Colquitt, J. A. (2001). On the Dimensionality of Organizational Justice: A Construct Validation of a Measure. Journal of Applied Psychology, 86(3), 386-400.

[16]. Folger, R., \&Konovsky, M.A. (1989). Effects of procedural and distributive justice on reactions to pay raise decisions. Academy of Management Journal, 32, 851-66.

[17]. Folger, R., \&Cropanzano, R. (1998).Organizational justice and human resource management. London: Sage.

[18]. Fu, Y., \&Lihua, Z. (2012). Organizational justice and perceived organizational support: The moderating role of conscientiousness in China. Nankai Business Reviw International, 3(7), 145-166.

[19]. Greenberg, J. (1993). The social side of fairness: interpersonal and informational classes of organizational justice. In Cropanzano, R (Ed.), Justice in the Workplace: Approaching Fairness in Human Resource Management. Hillsdale, NJ: Lawrence-Erlbaum.

[20]. Hackett, R. D., Lapierre, L. M., \&Hausdorf, P. A. (2001). Understanding the links between work commitment constructs. J. Voc. Behav. , 58, 392-413.

[21]. Janssen, O., Lam, C. K., \& Huang, X. (2009). Emotional exhaustion and job performance: The moderating roles of distributive justice and positive affect. Journal of Organizational Behavior, 31(6), 787-809. 
[22]. Kets de Vries, M. F. R. (1993). The dynamics of family controlled firms: The good and the bad news. Organizational Dynamics, 21(3), 59-71.

[23]. Korsgaard, M. A., \& Roberson, L. (1995). Procedural justice in performance evaluation: The role of instrumental and noninstrumental voice in performance appraisal discussions. Journal of Management, 21, 657-669.

[24]. Mael, F. A., \&Ashforth, B. E., (1992). Alumni and their alma matter: a partial test of the reformulated model of organizational identification. Journal of Organizational Behavior, 13, pp. 103-123.

[25]. Mayhew, M. G., Ashkanasy, N. M., Bramble, T., \& Gardener, J. (2007).A Study of the Antecedents and Consequences of Psychological Ownership in Organizational Settings.The Journal of Social Psychology, 147(5), 477-500.

[26]. Meyer, J. P., \& Allen, N. J. (1991).A Three Component Conceptualization of Organizational Commitment.Human Resource Management Review, 1, 61-89.

[27]. Meyer, J. P., Stanley, D. J., Herscovitch, L., \&Topolnytsky, L. (2002). Affective, Continuance, and Normative Commitment to the Organization: A Meta-analysis of Antecedents, Correlates, and Consequences. Journal of Vocational Behavior, 61, 20-52.

[28]. Mowday, R.T., Porter, L.W., \& Steers, R.M. (1982).Employees organizational linkages: The psychology of commitment, absenteeism and turnover. New York: Academic Press.

[29]. Lind, E. A., Kanfer, R., \&Earley, R. (1990). Voice, control, and procedural justice: Instrumental and noninstrumental concerns in fairness judgment. Journal of Personality and Social Psychology, 59, 952-959.

[30]. Lind, E.A., \& Tyler, T.R. (1988).The Social Psychology of Procedural Justice, New York: Plenum Publishing.

[31]. Linda, S.B.J., \& Ping, T.T.L. (1996).Distributive and procedural justice as related to satisfaction and commitment.Advanced Management Journal, 61 (3), p. 25.

[32]. Loi, R., Hang-Yue, N., \& Foley, S. (2006). Linking employees' justice perceptions to organizational commitment and intention to leave: the mediating role of perceived organizational support.Journal of Occupational and Organizational Psychology, 79, 101-20.

[33]. O'Driscoll, M. P., Pierce, J. L., \&Coghlan, A. M. (2006). The psychology of ownership: Work environment structure, organizational commitment and citizenship behaviours. Group \& Organization Management, 31(3), 388-416.

[34]. Olkkonen, M. E., \&Lipponen, J. (2006).Relationships between organizational justice, identification with organization and work unit, and group-related outcomes.Organizational Behavior and HumanDecision Processes, 100(2), $202-215$.

[35]. O'Reily, C., \& Chatman, J. (1986). Organizational commitment and psychological attachment: The effects of compliance, identification, and internalization on prosocial behavior. Journal of Applied Psychology, 71, 492-499.

[36]. Pierce, J. L., Kostova, T., \& Dirks, K. T. (2001). Towards a theory of psychological ownership in organizations.Academy of Management Review, 26(2), 298-310.

[37]. Pierce, J. L., Kostova, T., \& Dirks, K. T. (2003). The state of psychological ownership: Integrating and extending a century of research. Review ofGeneral Psychology, 7, 84-107.

[38]. Pierce, J. L., \& Rodgers, L. (2004). The psychological of ownership and worker-owner productivity.Group and Organizational Management, 29, 588-613.

[39]. Porter, L., Steers, R., Mowday, R., \&Boulian, P. (1974). Organizational commitment, job satisfaction, and turnover among psychiatric technicians.Journal of Applied Psychology, 59, 603-609.

[40]. Roberson, Q. M., Moye, N. A., \& Locke, E. A. (1999).Identifying a missing link between participation and satisfaction: The mediating role of procedural justice perceptions.Journal of Applied Psychology, 84, 585-593.

[41]. Sapienza, H. J., \&Korsgaard, M. A. (1996).Procedural justice in entrepreneur-investor relations.Academy of Management Journal, $39,544-574$.

[42]. Shu, S. B., \& Peck, J. (2011). Psychological ownership and affective reaction: Emotional attachment process variables and the endowment effect. Journal of Consumer Psychology, 21, 439-452.

[43]. Sieger, P., Bernhard, F., \& Frey, U. (2011).Affective commitment and job satisfaction among non-family employees: Investigating the roles of justice perceptions and psychological ownership. Journal of Family Business Strategy, 78-89.

[44]. Sweeney, P.D., \&McFarlin, D.B. (1993). Workers' evaluations of the 'ends' and the 'means': an examination of four models of distributive and procedural justice. Organizational Behavior and Human Decision Processes, 55, 23-40.

[45]. Thibaut, J., \& Walker, L. (1975).Procedural justice: A psychological analysis. Hillsdale, NJ: Erlbaum.

[46]. Tyler, T. R., Degoey, P., \& Smith, H. (1996). Understanding why the justice of group procedures matters: A test of the psychological dynamics of the group-value model. Journal of Personality andSocial Psychology,70, 913-930.

[47]. Tyler, T. R., \&Blader, S. L. (2000).Cooperation in groups: Procedural justice, social identity and behavioral engagement. Philadelphia, US:Psychology Press.

[48]. Tyler, T. R., \&Blader, S. L. (2003). The group engagement model: Procedural justice, social identity, and cooperative behavior. Personalityand Social Psychology Review, 7, 349-361.

[49]. Usmani, S., \& Jamal, S. (2013). Impact of Distributive Justice, Procedural Justice, Interactional Justice, Temporal Justice, Spatial Justice on Job Satisfaction of Banking Employees.Review of Integrative Business \& Economics Research, 2(1), 351-383.

[50]. Van Dyne, L., \& Pierce, J. L. (2004). Psychological ownership and feelings of possession: Three field studies predicting employee attitudes and organizational citizenship behaviour. Journal of Organizational Behaviour, 25(4), 439-459.

[51]. Walumbwa, F., Cropanzano, R., \&Hartnell, C. A. (2009). Organizational justice, voluntary learning behavior, and job performance: A test of the mediating effects of identification and leader-member exchange. Journal of Organizational Behavior, 30(8), 11031126.

[52]. Welbourne, T. M., Balkin, D. B., \& Gomez-Mejia, L. R. (1995). Gainsharing and mutual monitoring: A combined agencyorganizational justice interpretation. Academy of Management Journal, 38, 881-899. 